\title{
Bioactive compounds and antioxidant capacity of domestic citrus cultivar 'Haryejosaeng'
}

\author{
Sang Suk Kim*, Kyung Jin Park, Su Hyun Yun, Young Hun Choi \\ Citrus Research Institute, National Institute of Horticultural \& Herbal Science, RDA, Jeju 63607, Korea
}

\section{국내육성 품종 ‘하례조생’의 생리활성 성분과 항산화 활성}

\author{
김상숙*·박경진 · 윤수현 · 최영훈 \\ 국립원예특작과학원 감귤연구소
}

\begin{abstract}
A new early maturing satsuma mandarin (Citrus unshiu Marc.) 'Haryejosaeng' was developed at the Citrus Research Institute, Korea. The present study investigated the variation in total phenolics (TP), flavonoid, and antioxidant activity of fruits of 'Haryejosaeng' according to the harvest from September 2018 to December 2018, in Jeju. Colorirmetric methods were employed for the quantitative TP analysis, and the antioxidant activity by in vitro assay methods for DPPH, ABTS, hydroxyl radical, superoxide anion radical, nitric oxide, and hydrogen peroxide. The flavonoid and carotenoid compositions of 'Haryejosaeng' were compared with HPLC method. The total phenolics contents, flavonoid, antioxidant activity in both peel and flesh of 'Haryejosaeng' decreased during ripening. However, the amounts of $\beta$-cryptoxanthin in flesh increased from 0.2 to $1.86 \mathrm{mg} / 100 \mathrm{~g}$ during ripening. The major flavonoids of 'Haryejosaeng' extract were narintin, hesperidin, rutin, nobiletin, and tangeretin. The changes observed for the antioxidant activity of 'Haryejosaeng' was correlated with the content of flavonoid and phenolics which can indicate that these compounds may act by capturing free radicals. Therefore, these results suggest that fruits of 'Haryejosaeng' are a significant source of antioxidant compounds such as phenolics, flavonoid and $\beta$-cryptoxanthin. These finding will allow the determination of appropriate times for harvesting Haryejosaengs containing the highest amount of specific bioactive makers for achieving improved health benefits and functional properties.
\end{abstract}

Key words : Haryejosaeng, flavonoid, $\beta$-cryptoxanthine, antioxidant activity

\section{서 론}

현대 사회는 불규칙한 식습관, 운동 부족과 식생활의 서 구화 등에 따른 생활의 변화로 비만 등이 유발되어 대사질 환인 고혈압과 당뇨의 발병이 증가하고, 인간의 수명이 증 가하면서 노화 및 심혈관 질환 등이 급증하는 추세이다. 인체 노화의 요인 중 하나인 활성산소는 세포의 파괴, 피부 질환 및 피부노화 여러 가지 형태로 노화를 촉진시키고

*Corresponding author. E-mail : sskim0626@korea.kr Phone : 82-64-730-4153, Fax : 82-64-730-4111

Received 08 July 2019; Revised 26 August 2019; Accepted 30 August 2019.

Copyright (c) The Korean Society of Food Preservation. All rights reserved.
질병을 유도하는 원인중 하나로 알려지고 있다. 활성 산소 는 세포호흡 과정에서 발생하며 외부로부터 인체 내로 침입 하는 병원체를 효과적으로 제거할 뿐만 아니라(1), 체내에 서 발생하는 기형 세포와 조직, 기타 노화 세포들을 제거하 는 역할을 하는 등 인체 면역 염증반응의 긍정적인 역할을 담당하고 있다. 하지만 과도하게 생성된 활성산소는 단백 질 분해, 지질 과산화, DNA 변형 등을 초래하여 활성산소 의 산화적 대사산물인 자유라디칼은 반응성이 커서 인체 세포와 반응하여 세포막을 변형시켜(2-4) 세포 사멸을 유도 하게 되어 조직 내에 치명적인 손상으로 암, 알츠하이머, 파킨슨병 등을 유발하게 된다 $(5,6)$. 이에 활성 산소를 제거 하기 위해 항산화력이 우수한 합성 항산화제인 butylated hydroxytoluene, butylated hydroxyanisole 등이 개발되었다. 그러나 과량 섭취할 경우 지질변화, 신장, 간, 폐, 위장 점막, 
순환계 등에 독성을 일으키는 부작용이 알려져 안전성의 문제가 제기되면서 $(7,8)$ 사용을 자제하고 있다. 합성 항산 화제의 부작용으로 인해 천연유래 항산화제가 개발되었고 그중 녹차나 포도에 함유된 폴리페놀류의 catechin 등이 대표적이며(9), 각종 생약제, 과일, 채소에서 천연물 유래의 항산화제를 개발 이용하고자 하는 연구가 진행 중이다.

감귤은 다양한 유용 성분을 함유하고 있는 것으로 알려 져 있으며 항산화, 항암, 항염증 등의 효과를 갖는 flavonoid 를 비롯하여 carotenoid, vitamin $\mathrm{C}$, 구연산, 펙틴 등과 같은 기능성 성분을 함유하고 있는 중요 식품 소재이다. 특히 감귤류에 함유되어 있는 flavonoid 성분은 약 60여종이 존재 하는 것으로 알려져 있으며, 그 중 nobiletin과 tangeretin은 다른 채소나 과일에서 보고되지 않은 polymethoxyflavonoid 로 혈소판 응집 억제, 임파구 증식 억제, 항궤양, 항염증 등의 생리활성을 나타내는 것으로 보고되고 있다 $(10,11)$. 감귤은 세계적으로 생산량이 가장 많은 중요 과수 작물로 열대 및 아열대 지역을 중심으로 광범위하게 재배되고 있다 (12). 그 중 국내육성 품종 '하례조생'은 고품질의 감귤 과실 생산과 제주도 기후 및 토질에 맞는 육성된 조생계 온주밀 감 품종으로 2004년 최종 선발되어 2015년 품종 등록되었 다. 하례조생은 '입간조생'과 '하귤'을 교배하여 나온 주심 배실생으로 당 함량이 높고, 산 함량이 낮아 고품질과 생산 이 용이한 품종이다. 이러한 국내육성 품종 '하례조생'에 대한 유용성분 분석 및 활성산소종을 제거하는 항산화 활성 에 대한 연구는 미미한 실정이다. 이에 본 연구에서는 하례 조생의 시기별 총 폴리페놀 함량, 플라보노이드, 베타 크립 토잔틴 성분 분석과 항산화 활성 연구를 수행하여 천연물 유래 생리활성 기능성 신소재를 발굴하고자 하였다.

\section{재료 및 방법}

\section{실험재료}

본 연구에 사용된 하례조생은 2018년 9월부터 12월까지 국립원예특작과학원 감귤연구소에서 시료를 채집하여 실 험을 수행하였다. 시기별로 채집된 '하례조생'은 과육과 과피를 분리하여 건조 후 분쇄하여 $70 \%$ 에탄올로 3 회 반복 추출하였다. $70 \%$ 에탄올 추출물은 농축 후 사용하였으며 추출 수율은 28-35\%로 나타났다. DPPH, ABTS, sodium nitroprusside, folin-ciocalteus, thiobarbituric acid, EDTA 등 항산화 활성 분석을 위한 시약은 Sigma-Aldrich Co.(St, Louis, MO, USA)로부터 구입하여 사용하였다.

\section{총 폴리페놀 함량 측정}

‘하례조생' 추출물의 총 폴리페놀 함량은 Folin-Denis(13) 법을 이용하여 비색 정량하였다. 추출물 $100 \mu \mathrm{L}$ 에 증류수 $900 \mu \mathrm{L}$ 를 넣고, Folin-ciocalteus' phenol reagent $100 \mu \mathrm{L}$ 를
첨가하여 실온에서 5 분간 반응 시킨 후 $\mathrm{Na}_{2} \mathrm{CO}_{3}$ 용액 $(7 \%$, w/v) $200 \mu \mathrm{L}$ 와 증류수 $700 \mu \mathrm{L}$ 를 넣어 실온에서 1시간 반응 시켰다. 흡광도는 SpectraMax ${ }^{\circledR}$ M3 Multi-Mode Microplate Reader(Molecular Devices, Sunnyvale, CA, USA)를 이용하 여 $720 \mathrm{~nm}$ 에서 측정하였고, gallic acid를 이용하여 작성한 표준검정곡선을 이용하여 추출물의 총 폴리페놀 함량을 나타내었다.

\section{DPPH radical scavenging 활성 측정}

DPPH radical 소거 활성 실험은 Blosis 방법(14)을 사용하 였다. $0.2 \mathrm{mM}$ 로 준비된 $\mathrm{DPPH}$ 용액과 농도별로 준비된 시료를 섞어 실온에서 10 분간 방치한 후 $517 \mathrm{~nm}$ 에서 흡광 도를 측정하였으며, 각 시료는 3회 반복실험을 실시하여 평균값을 구하였다. 이 때 사용된 대조군으로는 ascorbic acid를 사용하였다.

\section{ABTS radical scavenging 활성 측정}

ABTS radical 소거활성은 $7.4 \mathrm{mM}$ ABTS와 $2.6 \mathrm{mM}$ potassium persulfate를 혼합 후 실온 암소에서 15시간 동안 방치하여 radical을 형성시킨 후 이 용액을 $734 \mathrm{~nm}$ 에서 흡광 도 값이 $0.70 \pm 0.02$ 가 되도록 준비하였다(15). 준비된 ABTS 용액 $180 \mu \mathrm{L}$ 에 추출물 $20 \mu \mathrm{L}$ 를 가하여 실온에서 15 분 동안 방치한 다음 $734 \mathrm{~nm}$ 에서 흡광도를 측정하였다. ABTS radical 소거활성은 시료 용액의 첨가구와 무첨가구 사이의 흡광도 차이를 백분율로 나타내었다.

\section{Nitric oxide(NO) radical scavenging 활성 측정}

NO radical 소거 활성은 Marcocci 등(16)의 방법을 변형하 여 측정하였다. 농도별로 준비된 시료 $100 \mu \mathrm{L}$ 와 $\mathrm{PBS}$ 에 녹인 $5 \mathrm{mM}$ sodium nitroprusside $100 \mu \mathrm{L}$ 를 $25^{\circ} \mathrm{C}$ 에서 30 분간 반응 시킨다. 반응이 끝난 후 Griess reagent $100 \mu \mathrm{L}$ 를 첨가한 후 $25^{\circ} \mathrm{C}$ 에서 15 분간 반응 후 $540 \mathrm{~nm}$ 에서 흡광도를 측정한 다.

\section{Hydroxyl radical scavenging 활성 측정}

Hydroxyl radical 소거활성은 Kunchandy와 Rao(17)의 방 법을 변형하여 사용하였다. 실험을 위해 준비한 reaction mixture $(1 \mathrm{~mL})$ 는 $28 \mathrm{mM}$ 2-deoxy-D-ribose $100 \mu \mathrm{L}, 1.04 \mathrm{mM}$ EDTA $100 \mu \mathrm{L}, 200 \mu \mathrm{M} \mathrm{FeCl}_{3} 100 \mu \mathrm{L}, 1 \mathrm{mM} \mathrm{H}_{2} \mathrm{O}_{2} 100$ $\mu \mathrm{L}, 1 \mathrm{mM}$ ascorbic acid $100 \mu \mathrm{L}$ 로 준비되어 있는 용액에 추출물 $500 \mu \mathrm{L}$ 를 혼합 후 $37^{\circ} \mathrm{C}$ 에서 1 시간 반응시킨다. 반응 이 끝난 후 $1 \%$ 의 thiobarbituric acid $1 \mathrm{~mL}$ 와 $2.8 \%$ trichloroacetic acid $1 \mathrm{~mL}$ 을 첨가한 후 $100^{\circ} \mathrm{C}$ 에서 20 분간 반응 후 식힌 다음 $532 \mathrm{~nm}$ 에서 흡광도를 측정하였다.

\section{Hydrogen peroxide scavenging activity}

Hydrogen peroxide 소거 활성 측정은 농도별 시료 $20 \mathrm{uL}$ 
에 $0.1 \mathrm{mM} \mathrm{H}_{2} \mathrm{O}_{2}, 50 \mathrm{mM}$ sodium phosphate buffer를 넣고 $37^{\circ} \mathrm{C}$ 에서 5 분간 반응하였다. 반응이 끝난 용액에 $0.1 \mathrm{mM}$ $\mathrm{ABTS}$ 와 $0.15 \mathrm{U} / \mathrm{mL}$ peroxidase를 혼합하여 $37^{\circ} \mathrm{C}$ 에서 10 분 간 반응 후 $405 \mathrm{~nm}$ 에서 흡광도를 측정하였다.

\section{FRAP법에 의한 항산화 활성 측정}

FRAP(ferric reducing antioxidant power)법에 의한 항산화 활성은 96 well plate에 시료 $20 \mu \mathrm{L}, \mathrm{FRAP}$ 기질액 $(300 \mathrm{mM}$ acetate buffer(pH 3.6), $40 \mathrm{mM} \mathrm{HCl}$ 에 용해한 $10 \mathrm{mM} \mathrm{TPTZ}$ (2,4,6-tripyridyl-s-triazine) 용액, $20 \mathrm{mM} \mathrm{FeCl} 3 \cdot 7 \mathrm{H}_{2} \mathrm{O}$ 를 각각 $10: 1: 1(\mathrm{v} / \mathrm{v} / \mathrm{v})$ 로 혼합한 용액 $180 \mu \mathrm{L}$ 를 넣어 혼합한다(18). 혼합 용액은 암소에서 30 분간 반응시킨 후 $590 \mathrm{~nm}$ 에서 흡광도를 측정하였으며, $\mathrm{FeCl}_{3} \cdot 7 \mathrm{H}_{2} \mathrm{O}$ 를 표준물질로 하여 얻 은 표준검정곡선으로부터 계산하였다.

\section{HPLC를 이용한 bioactive compound 분석}

Flavonoid 성분 분석을 위한 시료는 $70 \%$ 에탄올로 추출, 농축하여 용매에 녹여 $0.22 \mu \mathrm{m}$ PVDF filter(Merck KGaA, Darmstadt, Germany)로 여과한 후 High Performance Liquid Chromatography(HPLC, e2695 Separations module, Waters Co., Ltd., Miliford, MA, USA)를 이용하여 분석하였다. 분석 에 사용한 column은 YMC-Triart C18, 250×4.6 mm, S-5 $\mu \mathrm{m}$, $8 \mathrm{~nm}$ 을 사용하였고 detector는 UV/Visible Detector(Waters 2489, Waters Co., Ltd., Miliford, MA, USA)을 사용하였다. 유속은 $1 \mathrm{~mL} / \mathrm{min}$ 을 유지하였고 UV $280 \mathrm{~nm}$ 에서 검출하였 다. 표준물질은 감귤류에 많이 함유되어 있는 10 종의 플라 보노이드를 사용하였으며 종류에 따라 3가지 조건으로 나 누어 분석하였다. Rutin, narirutin, naringin, hesperidin, neohesperidin은 이동상 조건이 acetonitrile: $20 \mathrm{mM}$ phosphoric acid=2:8이다. Quercetin, naringenin, hesperetin 의 분석을 위한 이동상 조건은 acetonitrile: $20 \mathrm{mM}$ phosphoric acid=4:6으로 수행하였고, nobiletin과 tangeretin 의 이동상 조건은 acetonitrile: $20 \mathrm{mM}$ phosphoric acid= 6:4 로 수행하였으며 모든 시약은 HPLC grade를 사용하였다. 표준검량선 작성은 각각의 표준물질을 에탄올로 $1: 1$ 비율 로 6단계 희석하여 $15.625 \mu \mathrm{g} / \mathrm{mL}$ 부터 $1,000 \mu \mathrm{g} / \mathrm{mL}$ 의 농도 의 표준물질을 이용하여 작성하였다. 표준물질로 작성된 표준검량선으로 플라보노이드 성분들의 정량 분석에 사용 하였다.

$\beta$-cryptoxanthine 분석은 YMC C18-triart 컬럼을 사용하 였고, 전개용매로는 ethyl acetate:acetonitrile(with $0.2 \%$ formic acid)를 60:40, flow rate은 $1 \mathrm{~mL} / \mathrm{min}$ 으로 HPLC를 수행하였다. 데이터 분석 S/W는 Waters의 Empower System 을 사용하였다.

\section{통계분석}

모든 실험은 3회 이상 반복하여 이루어졌으며, 실험 결과
는 각 항목에 따라 평균과 표준편차로 나타내었다. 실험군 과의 차이는 SAS package(Statistical Analysis Program, version 9.1)을 사용하여 Duncan's mutiple range test로 평균 을 비교하여 나타내었고, $\mathrm{p}<0.05$ 수준에서 통계적 유의성을 검정하였다.

\section{결과 및 고찰}

\section{총 폴리페놀 함량}

식물계에 널리 분포되어 있는 페놀류 화합물은 강한 항 산화 활성으로 자유라디칼 소거 활성이 우수하며, 다양한 구조와 분자량을 가지는 것으로 알려져 있다. 페놀류 화합 물은 phenolic hydroxyl(-OH)기를 갖고 있어 단백질 및 기타 거대분자들과 쉽게 결합하여 효과적으로 활성산소종을 제 거한다. 또한 산화 및 노화를 억제하는 항산화 효과뿐만이 아니라 항암, 콜레스테롤 저해, 정장 작용 등 다양한 생리활 성을 가지는 것으로 알려져 있다(19-21). 이러한 페놀류 화 합물은 특히 감귤에 다량 함유되어 있는 것으로 알려져 있다, 감귤류 중 국내 육성 품종인 하례조생의 과육(HRFE) 과 과피(HRPE) 추출물에서 시기별로 총 폴리페놀 함량을 분석하여 기능성 소재로 활용하기 위한 적절한 시기를 알아 보고자 하였다. 시기별 함량 분석을 위해 9월부터 한 달 간격으로 12 월까지 채집하였고 총 폴리페놀 함량 측정을 위해 gallic acid를 표준물질로 사용하였으며, 그 결과는 Fig. 1 에 나타내었다. 하례조생의 총 폴리페놀 함량은 9월의 $\mathrm{HRFE}$ 와 HRPE에서 $2.95 \mathrm{mg} / 100 \mathrm{~g}$ 과 $4.92 \mathrm{mg} / 100 \mathrm{~g}$ 함량으 로 가장 높았으며, 완숙 될수록 감소하는 것을 확인 할 수 있었다. 완숙될수록 감소하는 총 폴리페놀 함량은 미숙과 시기인 9 월과 12 월 과피에서는 약 1.5 배의 함량 차이를 보 여 함량의 변화는 과피에서 더 크게 나타나는 것을 확인할 수 있었다. 미숙과 시기에 총 폴리페놀 함량이 높은 결과는

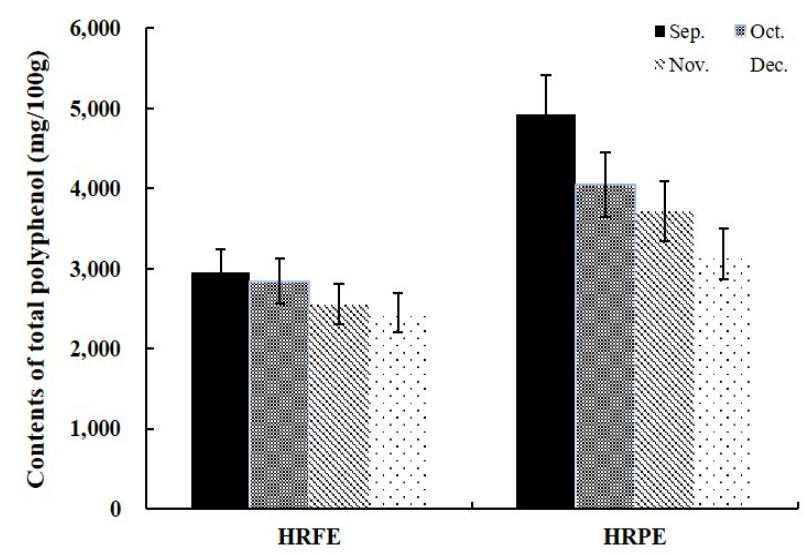

Fig. 1. Total polyphenol contents of HRFE and HRPE.

Results are mean $\pm \mathrm{SD}$ of data from three derterminations recorded for at least two independent extractions. HRFE: Haryejoseang flesh extract. HRPE: Haryejoseang peel extract. 
재래귤인 병귤을 이용한 시기별 폴리페놀 함량 분석 결과와 도 유사하게 나타났다(22). 이러한 시기별로 다른 폴리페놀 류 화합물의 함량은 항산화 활성에 영향을 미칠 것으로 예상하여 다양한 방법으로 항산화 활성을 측정해 보고자 하였다.

\section{$\mathrm{DPPH}$ 와 ABTS radical 소거 활성}

시기별로 총 폴리페놀 함량에 차이를 보이는 하례조생 추출물의 항산화 활성 측정은 free radical 소거능을 보기 위한 DPPH, ABTS, hydroxyl, superoxide anion, NO radical 과 hydrogen peroxide 소거활성을 측정하였으며, 산화 및 환원 반응에 의한 메카니즘으로 항산화 활성을 측정하게 되는 FRAP를 측정하였다. 항산화 활성 측정 방법 중 가장 간편하면서 신뢰성이 높아 많이 사용되고 있는 $\mathrm{DPPH}$ radical 소거 활성은 화학적으로 유도되어 비교적 안정적인 DPPH radical이 전자를 공여 받으면 고유의 보라색이 없어 지는 것으로 활성을 측정하게 된다. 그 결과 $\mathrm{HRPE}$ 에서의 활성이 우수하였으며, 시기적으로는 총 폴리페놀 함량이 가장 높은 9월의 시료에서 가장 높았다. DPPH radical 소거 활성은 Fig. 2(A)에 나타낸 것처럼 $\mathrm{HRPE}$ 에서는 시기적으
로 $9,10,11,12$ 월에 $\mathrm{IC}_{50}$ 이 $0.78 \pm 0.05,1.13 \pm 0.09,1.26 \pm 0.13$, $1.29 \pm 0.13 \mathrm{mg} / \mathrm{mL}$ 이었고, $\mathrm{HRFE}$ 에서 $\mathrm{IC}_{50}$ 은 $2.01 \pm 0.15$, $2.21 \pm 0.19,3.04 \pm 0.21,3.08 \pm 0.28 \mathrm{mg} / \mathrm{mL}$ 인 것을 확인 할 수 있었다. $\mathrm{ABTS}$ radical 소거 활성은 $\mathrm{ABTS}$ 와 potassium persulfate가 반응하여 밝은 청색을 띤 ABTS radical을 형성 하며, 수소를 공여하는 항산화 활성을 지닌 물질과 반응 시 감소되면서 무색으로 변색된다. ABTS radical 역시 $\mathrm{DPPH}$ radcial과 같이 합성된 radical로 상당히 안정적이며, 수용성 및 지용성 물질에 모두 적용 가능하다는 점에서 항산화 활성 측정 시에 많이 이용되고 있다. $\mathrm{HRPE}$ 와 $\mathrm{HRFE}$ 의 ABTS radcial 소거 활성은 $\mathrm{HRPE}$ 에서 시기적으로 9, 10 , 11,12 월에 $0.14 \pm 0.01,0.19 \pm 0.01,0.22 \pm 0.02,0.27 \pm 0.03$ $\mathrm{mg} / \mathrm{mL}$, HRFE에서 $0.36 \pm 0.03,0.43 \pm 0.03,0.59 \pm 0.04$, $0.59 \pm 0.04 \mathrm{mg} / \mathrm{mL}$ 의 $\mathrm{IC}_{50}$ 의 활성을 보였으며, 이는 $\mathrm{DPPH}$ radcial 소거 활성과 같은 경향으로 HRPE 중 9월의 시료에 서 radical 소거활성이 가장 높았다.

$\mathrm{DPPH}$ 와 $\mathrm{ABTS}$ radical 소거활성은 양성 대조군인 ascorbic acid의 $\mathrm{IC}_{50}$ 인 $8.9 \mu \mathrm{g} / \mathrm{mL}$ 과 $6.6 \mu \mathrm{gg} / \mathrm{mL}$ 인 활성과 비교하면 낮은 활성이지만 총 폴리페놀 함량과 비례하여 radical 소거활성은 증가하는 것을 확인할 수 있었다. DPPH
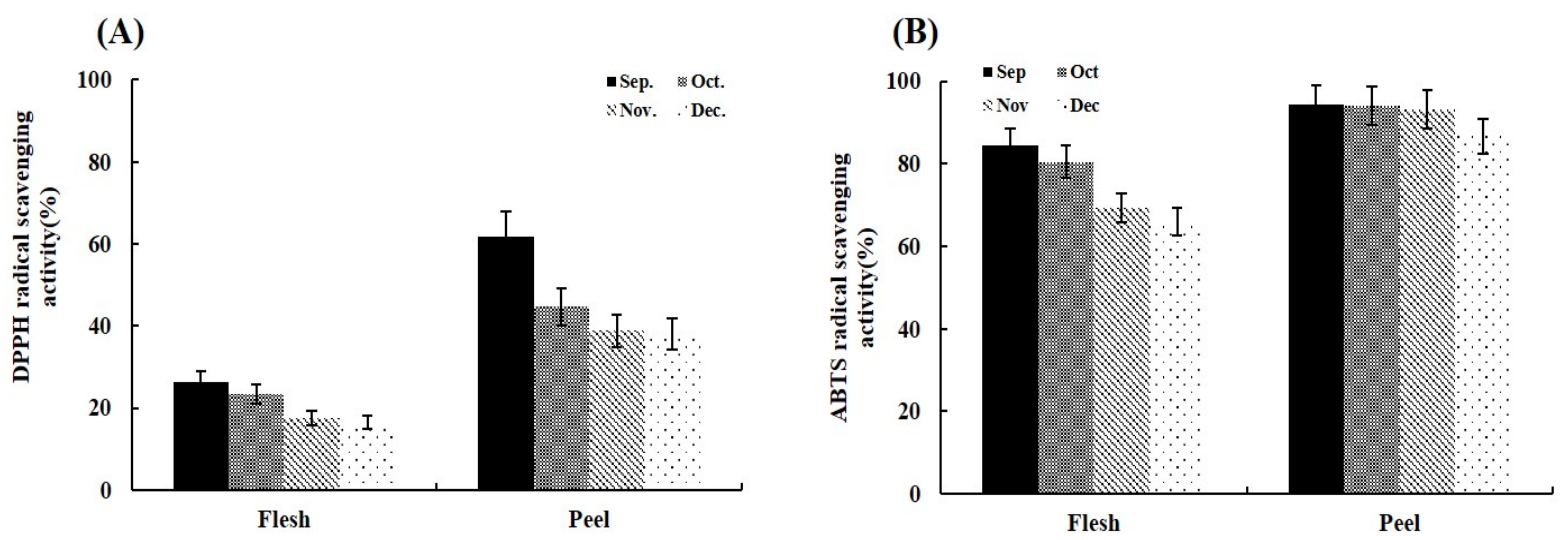

(C)

(D)
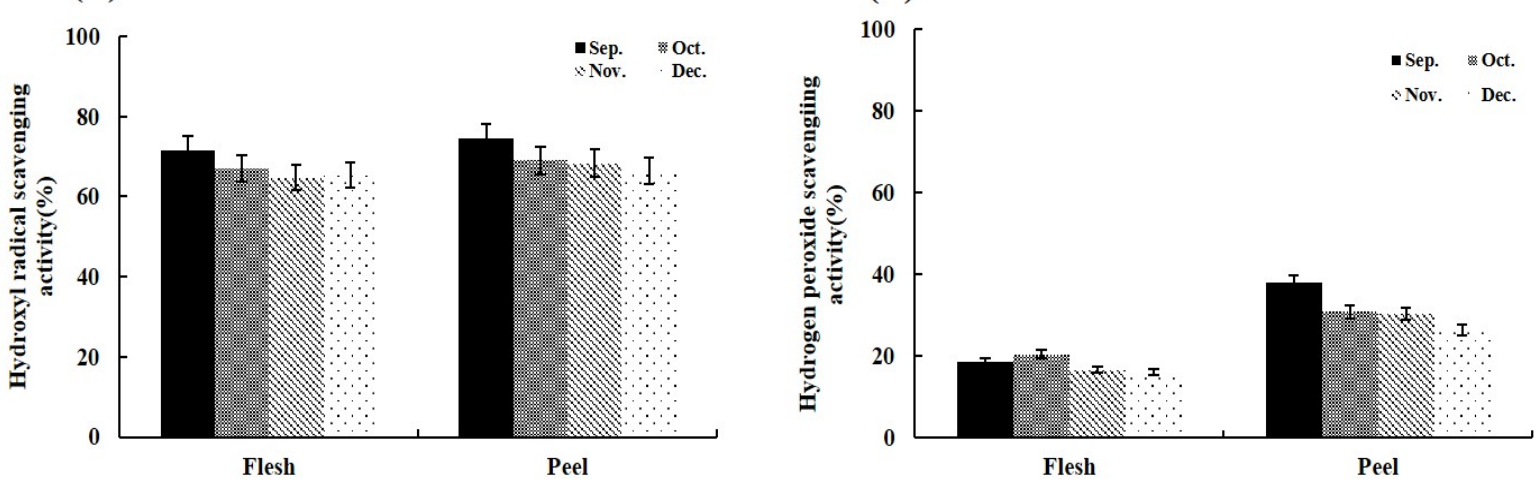

Fig. 2. Antioxidative activities of HRFE and HRPE. Free radical scavenging activity of (A) DPPH, (B) ABTS, (C hydroxyl, and (D) superoxide anion.

The data are presented as mean \pm standard deviation. Results are mean \pm SD of data from three determinations recorded for at least two independent extractions. HRFE: Haryejoseang flesh extract. HRPE: Haryejoseang peel extract. 
radical 소거활성에서 총 폴리페놀 함량과의 상관관계는 $\mathrm{R}^{2}=0.98$ ( $\mathrm{HRFE}$ )와 $\mathrm{R}^{2}=0.75$ (HRPE)로 나타났다(data not shown).

\section{Superoxide anion과 hydroxyl radical 소거 활성}

Superoxide anion, hydroxyl, NO radical과 hydrogen peroxide과 같은 활성산소종(ROS)은 정상적인 세포내 필요 한 에너지 생산을 위한 생화학적인 산화과정에서 생성되 며, 비공유전자를 갖고 있기 때문에 매우 불안정하고 반응 성이 높아 생체내 세포와 조직의 구성성분을 쉽게 공격하는 것으로 알려져 있다(23), 특히 hydroxyl radical은 반응성이 매우 크고 반응 속도가 빠르며 지질의 산화 및 DNA에 손상 을 주고 돌연변이를 유발하여 다양한 질환에 관여하는 자유 라디칼 중 가장 강한 독성을 갖는 활성산소이다. 이러한 hydroxyl radical에 HRFE와 HRPE 모두 강한 항산화 활성을 보였으며 9월의 $\mathrm{HRPE}$ 에서 $\mathrm{IC}_{50}$ 이 $0.126 \mathrm{mg} / \mathrm{mL}$ 로 가장 우 수하였으며 이는 $\mathrm{HRFE}$ 에서 가장 활성이 우수한 9월의 활 성 $(0.228 \mathrm{mg} / \mathrm{mL})$ 보다도 1.8 배 활성이 높았다(Fig. 2(C)). 또 한 superoxide anion radical 소거 활성에서 역시 HRPE에서 활성이 우수하였으며 그 중 $\mathrm{HRPE}$ 9월의 시료에서는 $\mathrm{IC}_{50}$ 이 $0.14 \mathrm{mg} / \mathrm{mL}$ 로 HRFE에서 가장 우수한 활성인 9월 시료의 $0.418 \mathrm{mg} / \mathrm{mL}$ 보다 약 3배나 높은 활성을 보였다(Fig. 2(D)). 양성 대조군인 ascorbic acid의 $\mathrm{IC}_{50}$ 은 $0.012 \mathrm{mg} / \mathrm{mL}$ 로 나타 났다. 이는 총 폴리페놀 함량이 가장 높은 $\mathrm{HRPE}$ 의 9월 시료에서 공통적으로 우수한 활성이 나타나고 있어, 하례 조생 추출물에 다량 함유되어 있는 페놀성 화합물의 영향으 로 여겨진다.

\section{Hydrogen peroxide와 NO 소거 활성}

활성산소종 중의 하나인 hydrogen peroxide는 과산화지 질의 생성을 촉진하는 것으로 알려져 있으며, 하례조생 추 출물인 $\mathrm{HRFPE}$ 와 $\mathrm{HRPE}$ 를 $10 \mathrm{mg} / \mathrm{mL}$ 의 농도로 처리 시
$\mathrm{HRFE}$ 에서는 $15 \%$ 미만의 저해활성을 보였고(data not shown), HRPE 중 9월의 시료에서는 $38 \%$ 의 저해활성을 확 인할 수 있었다(Fig. 3(A)). 이는 $50 \mathrm{\mu g} / \mathrm{mL}$ 농도의 ascorbic $\mathrm{acid}$ 가 갖는 $20 \%$ 소거 활성보다 높게 나타났다. $\mathrm{NO}$ 는 생체 내에서 NO synthase(NOS)라는 효소의 작용을 통해 L-arginine으로부터 생성되는 반응성이 강한 radical이다. 일반적인 $\mathrm{NO}$ 의 형성은 박테리아를 죽이거나 종양을 제거 시키는 중요한 역할을 하지만, 염증상태에서 iNOS에 의해 과잉 생산된 $\mathrm{NO}$ 는 혈관 투과성, 부종 등의 염증 반응을 촉진 시킬 뿐만 아니라 염증 매개체의 생합성을 촉진하여 염증을 심화시키는 것으로 알려져 있다. 이러한 NO 소거 활성 측정을 위해 $\mathrm{HRFE}$ 와 $\mathrm{HRPE}$ 를 처리하였으나 $\mathrm{HRFE}$ 에 서는 소거 활성을 확인 할 수 없었고, $\mathrm{HRPE}$ 는 $5 \mathrm{mg} / \mathrm{mL}$ 로 처리하였을 때 9 월의 시료에서 $40 \%$ 정도의 소거활성을 확인할 수 있었다(Fig. 3(B))(24,25).

\section{FRAP법에 의한 하례조생 추출물의 항산화 효과}

$\mathrm{HRFE}$ 와 $\mathrm{HRPE}$ 의 환원력을 알아보기 위해 FRAP 방법을 사용하였다. FRAP법은 총 항산화능을 측정하는 방법으로 낮은 $\mathrm{pH}$ 에서 환원제에 의해 ferri tripyridyltriazine $\left(\mathrm{Fe}^{3+}-\right.$ TPTZ) 복합체가 ferrous tripyridyltriazine( $\left.\mathrm{Fe}^{2+}-\mathrm{TPTZ}\right)$ 으로 환원되는 원리를 이용한 것으로 대부분의 항산화제가 환원 력을 가지고 있다는 점을 이용하여 개발된 방법이다. $\mathrm{HRFE}$ 와 $\mathrm{HRPE}$ 의 환원력을 측정한 결과 $9,10,11,12$ 월에서 농도 가 증가함에 따라 환원력도 증가하는 것을 확인할 수 있었 고, $0.5 \mathrm{mg} / \mathrm{mL}$ 의 농도에서 나타나는 시기별 추출물의 환원 력을 Fig. 4에 나타내었다. FRAP 환원력에서 역시 HRPE의 9월에 활성이 가장 우수하였다. 시기별 하례조생 추출물인 $\mathrm{HRFE}$ 와 $\mathrm{HRPE}$ 의 항산화 활성을 측정한 결과 $\mathrm{HRPE}$ 의 9월 에 항산화 활성이 가장 우수하였고, 이 시기에 총 폴리페놀 함량이 가장 많이 함유되어 있었다.

항산화 활성은 폴리페놀 화합물의 함량과 높은 상관관계
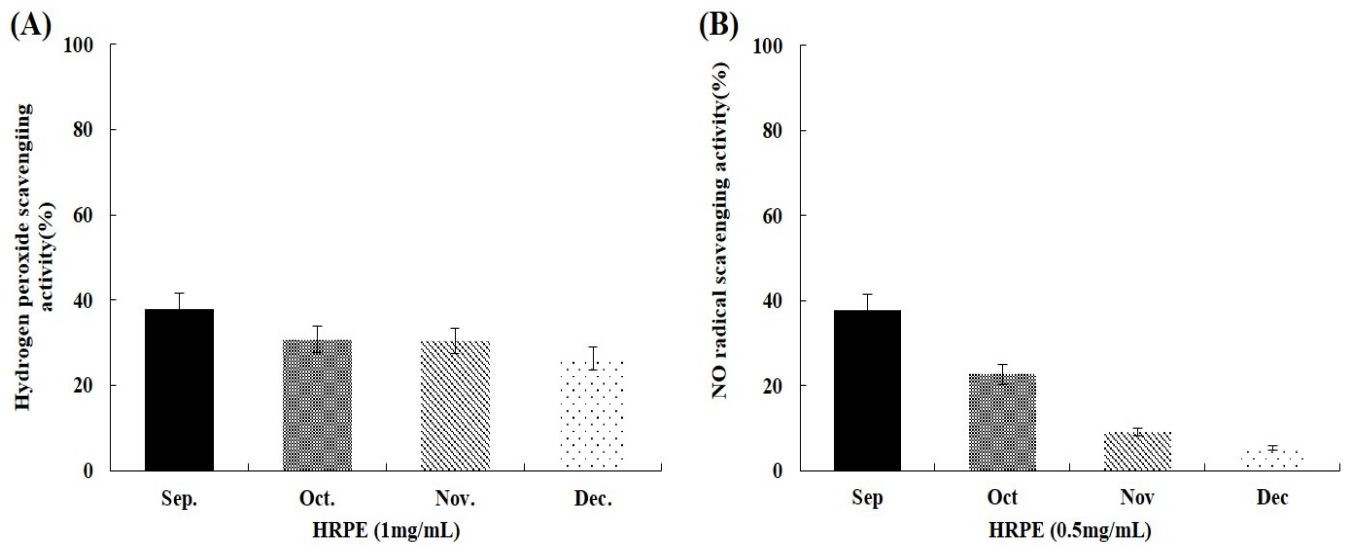

Fig. 3. Antioxidative activities of HRFE and HRPE. Free radical scavenging activity of (A) hydrogen peroxide, (B) nitric oxide.

The data are presented as mean \pm standard deviation. Results are mean \pm SD of data from three determinations recorded for at least two independent extractions. HRFE: Haryejoseang flesh extract. HRPE: Haryejoseang peel extract. 
(26)가 있다고 알려져 있다. 하례조생 추출물인 HRFE와 $\mathrm{HRPE}$ 역시 폴리페놀 함량과 비례하여 항산화 활성이 증가 하는 것을 확인 할 수 있었으며, 총 폴리페놀의 함량이 가장 높은 9월의 HRPE에서 항산화 활성이 가장 우수한 것으로 여겨진다.

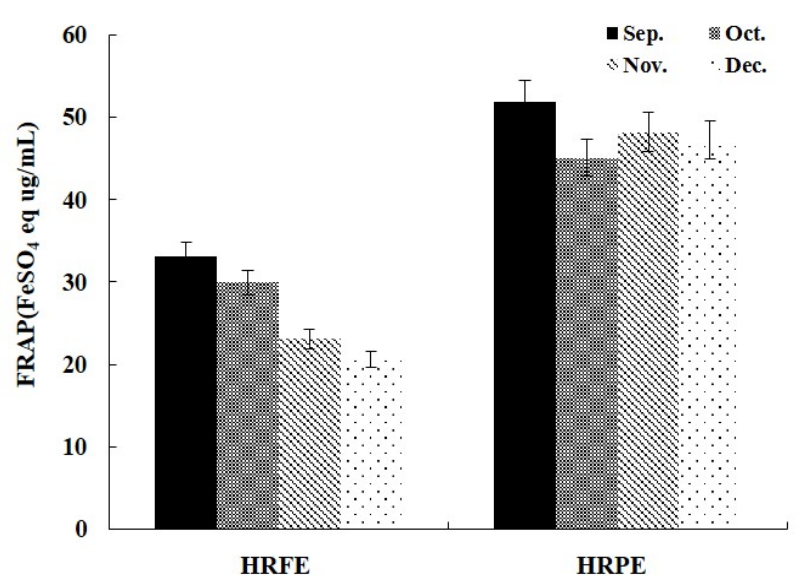

Fig. 4. Ferric ion reducing antioxidant powers of HRFE and HRPE.

The data are presented as mean \pm standard deviation. Results are mean \pm SD of data from three determinations recorded for at least two independent extractions. HRFE: Haryejoseang flesh extract. HRPE: Haryejoseang peel extract.

\section{플라보노이드 성분 및 함량 분석}

항산화 활성이 우수한 하례조생 추출물인 $\mathrm{HRFE}$ 와 HRPE의 bioactive 화합물 분석은 HPLC를 이용하여 감귤류 에 다량 함유되어 있는 것을 알려진 플라보노이드와 카로티 노이드를 분석하고자 하였다. 플라보노이드는 자연계에 널 리 분포하는 폴리페놀에 속하는 성분으로, $\mathrm{C6}-\mathrm{C} 3-\mathrm{C} 6$ 이 기 본 골격인 담황색 또는 노란색의 화합물로 flavanone, flavone, flavonol, isoflavone, anthocyanidin으로 구분할 수 있다(27). 감귤의 플라보노이드는 과피에 집중적으로 존재 하고, 감귤류에서만 보고되고 있는 polymethoxylated
flavones(PMF)인 nobiletin과 tangeretin이 포함되어 있어 혈 소판 응집 억제, 임파구 증식 억제, 항염증 등의 생리활성을 나타내는 것으로 알려져 있다. 플라보노이드는 시기별로 과육과 과피를 분리하여 추출한 $70 \% \mathrm{HRFE}$ 와 $\mathrm{HRPE}$ 를 이 용하여 분석하였다. $\mathrm{HRFE}$ 와 $\mathrm{HRPE}$ 의 플라보노이드 분석 은 배당체를 갖는 플라보노이드(rutin, narirutin, naringin, hesperidin, neohesperidin), 배당체가 없는 플라보노이드 (quercetin, naringenin, hesperetin), 그리고 메톡시기를 갖는 플라보노이드(nobiletin, tangeretin)(Fig. 5)로 나누어 분석하 였다. 그 결과 narirutin $>$ hesperidin $>$ rutin $>$ nobiletin $>$ tangeretin 순으로 함량이 높은 것을 확인 할 수 있었다(Table 1). 과육추출물인 $\mathrm{HRFE}$ 보다 과피추출물인 $\mathrm{HRPE}$ 에서 함량 이 더 높고, 시기적으로는 9월에 플라보노이드 함량이 가장 높았으며 완숙될수록 감소하는 것을 확인 할 수 있었다. 하례조생에 함유되어 있는 플라보노이드 중 미숙과 시기인 풋귤에서 높은 함량을 보이는 narirutin과 hesperidin은 풋귤 추출물을 이용한 화장품 등의 소재로 활용시 원료 표준화를 위한 지표성분으로 사용이 가능할 것으로 여겨진다. 또한 감귤류에만 함유되어 있는 것으로 알려진 $\mathrm{PMF}$ 인 nobiletin 과 tangeretin의 함량도 9 월의 과피 추출물에서 각각 $270.8 \pm 23.5 \mathrm{mg} / 100 \mathrm{~g}$ 과 $102.6 \pm 8.8 \mathrm{mg} / 100 \mathrm{~g}$ 으로 가장 높게 나타났다. 감귤류에만 다량 함유되어 있는 것으로 알려진 $\mathrm{PMF}$ 는 항바이러스, 항암, 항염 등의 활성과 활성 산소종으 로부터 피부를 보호하는 것으로 알려져 있으며, 감귤류 중 재래귤인 병귤과 진귤 등에서만 함량이 높게 나타났으나 하례조생의 bioactive 성분을 분석한 결과 미숙과 시기인 9월에 PMF의 함량이 높은 것을 확인 할 수 있었다.

\section{$\beta$-cryptoxanthin 함량 분석}

감귤류의 또 다른 지용성 색소 성분인 카로티노이드는 빨간색, 주황색, 노랑색을 내는 천연색소 성분으로 식물, 조류, 효모 등 자연계에 널리 분포되어 있으며, 600 여종의 카로티노이드 화합물이 보고되어 있다. 식품에 주로 존재

Table 1. Changes of flavonoid contents of flesh and peel of 'Haryejoseang' according to maturation

\begin{tabular}{|c|c|c|c|c|c|c|}
\hline & & Rutin & Narirutin & Hesperidin & Nobiletin & Tangeretin \\
\hline \multirow{4}{*}{$\underset{(\mathrm{mg} / 100 \mathrm{~g})}{\mathrm{HRPE}}$} & Sep & $523.9 \pm 48.2$ & $3094.1 \pm 199.9$ & $753.6 \pm 59.5$ & $270.8 \pm 23.5$ & $102.6 \pm 8.8$ \\
\hline & Oct & $399.9 \pm 23.6$ & $2605.2 \pm 154.1$ & $892.9 \pm 63.2$ & $189.5 \pm 16.6$ & $66.1 \pm 3.3$ \\
\hline & Nov & $160.1 \pm 10.2$ & $1586.5 \pm 102.6$ & $503.2 \pm 39.9$ & $70.6 \pm 4.6$ & $20.1 \pm 1.4$ \\
\hline & Dec & $99.49 \pm 6.5$ & $1047.8 \pm 88.3$ & $485.4 \pm 29.8$ & $65.5 \pm 5.9$ & $17.4 \pm 1.1$ \\
\hline \multirow{4}{*}{$\underset{(\mathrm{mg} / 100 \mathrm{~g})}{\mathrm{HRFE}}$} & Sep & $129.1 \pm 8.9$ & $1347.5 \pm 65.9$ & $226.1 \pm 20.3$ & $\mathrm{ND}$ & $\mathrm{ND}$ \\
\hline & Oct & $90.0 \pm 7.5$ & $966.8 \pm 48.7$ & $248.8 \pm 20.6$ & $\mathrm{ND}$ & $\mathrm{ND}$ \\
\hline & Nov & $84.8 \pm 5.5$ & $760.9 \pm 39.2$ & $249.2 \pm 21.4$ & $\mathrm{ND}$ & $\mathrm{ND}$ \\
\hline & Dec & $42.2 \pm 2.1$ & $566.0 \pm 22.3$ & $185.1 \pm 17.8$ & $\mathrm{ND}$ & $\mathrm{ND}$ \\
\hline
\end{tabular}

${ }^{*}$ HRFE, Haryejoseang flesh extract; HRPE, Haryejoseang peel extract. *ND: Not detected. 
(A)

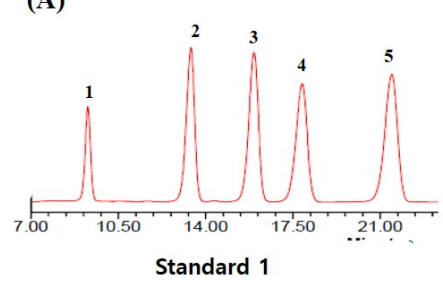

(D)

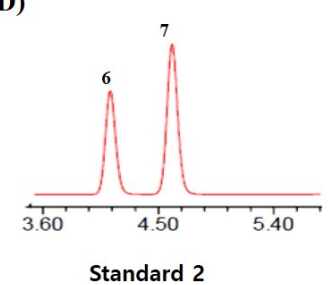

(B)

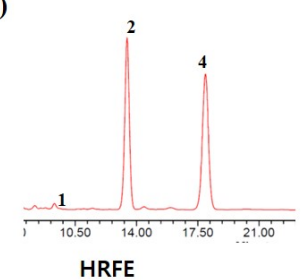

(E)

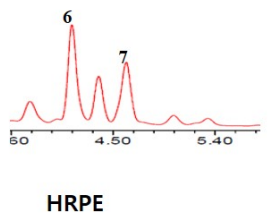

(C)

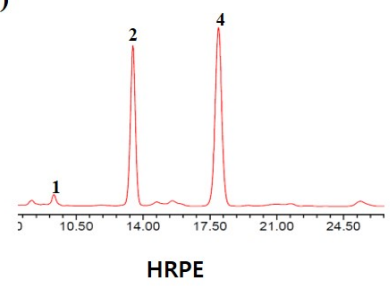

Fig. 5. HPLC chromatogram of flavonoids of standard, HRFE and HRPE.

A) standard 1 (1. Rutin; 2. Narirutin; 3. Naringin; 4. Hesperidin; 5. Neohesperidin,), (B) HRFE, (C) HRPE, (D) standard 2 (6. Nobiletin; 7. Tangeretin), (E) HRPE.

하는 카로티노이드는 lutein, zeaxanthin, $\beta$-cryptoxanthin, a -carotene, $\beta$-carotene, lycopene 등이 있으며, 비타민 $\mathrm{A}$ 의 전구체 역할과 함께 항산화, 항염, 심혈관질환 예방, 면역 활성 등이 보고되어 있다. 카로티노이드 성분 중 특히 감귤 류에 다량 함유되어 있고 폐경기 여성의 골다공증을 억제하 고 항암, 항염 등의 활성을 갖는 것으로 알려진 $\beta$ -cryptoxanthin을 하례조생에서 분석하고자 하였다 $(28,29)$. 그 결과 $\beta$-cryptoxanthin의 함량은 하례조생의 수확시기인 11 월과 12 월에 $1.86 \mathrm{mg} / 100 \mathrm{~g}$ 과 $1.72 \mathrm{mg} / 100 \mathrm{~g}$ 로 가장 높았 고, 플라보노이드 성분과 달리 완숙될수록 증가하는 것을 확인 할 수 있었다(Fig 6). 감귤의 과육에 다량 함유되어 있는 것을 확인 할 수 있었다.

감귤에 함유되어 있는 bioactive compound를 분석한 결과

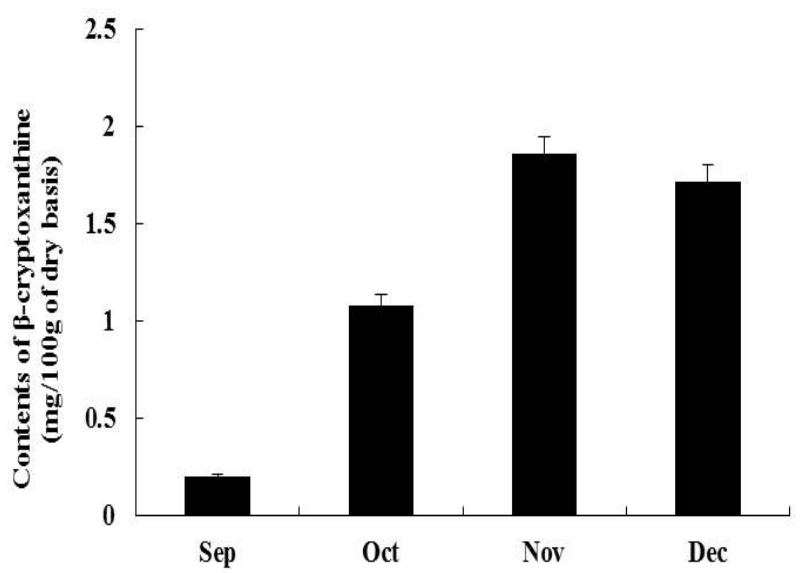

Fig. 6. The $\beta$-cryptoxanthin contents of HRFE according to maturation

Changes of $\beta$-cryptoxanthin contents of 'Haryejoseang' according to maturation. Results are mean $\pm \mathrm{SD}$ of data from three determinations recorded for at least two independent extractions. HRFE: Haryejoseang flesh extract.
완숙될수록 감소하는 성분과 증가하는 성분을 확인 할 수 있었으며 그 중 플라보노이드와 구연산 등은 완숙될수록 감소하고, $\beta$-cryptoxanthin과 비타민C의 경우는 완숙될 수 록 증가하는 것을 확인 할 수 있었다(data not shown). 시기 별로 다양한 bioactive 화합물을 함유하는 하례조생은 우수 한 항산화 및 항염 활성의 천연 소재로의 활용이 가능할 것으로 여겨진다.

\section{요 약}

국내 육성 품종인 하례조생 추출물의 총 폴리페놀 함량 과 항산화 활성을 분석한 결과 미숙과 시기인 9월 HRPE $(4.9 \mathrm{~g} / 100 \mathrm{~g})$ 에 가장 많이 함유되어 있었으며, 완숙될수록 점차 감소하는 것을 확인할 수 있었다. 시기별 페놀류 화합 물의 함량의 차이는 radical 소거 활성에 영향을 미쳐 $\mathrm{DPPH}$, ABTS, superoxide anion, hydroxyl, NO 라디칼의 소거 활성 역시 HRPE의 9월 시료에서 가장 높았으며, FRAP를 이용한 환원력 시험에서도 9월의 시료에서 활성이 가장 우수한 것을 확인할 수 있었다. 또한 HPLC를 이용한 분석 결과 주요 flavonoid로 rutin, narirutin, hesperidin, nobiletin, tengeretin이 함유되어 있었다. Flavonoid 역시 HRPE의 미숙 과 시기인 풋귤의 시기인 9월에 가장 함량이 높았고, 특히 polymethoxyflavonoid인 nobiletin과 tangeretin이 다량 함유 되어 있는 것을 확인할 수 있었다, 또한 감귤류의 지용성 색소 성분인 카로티노이드 중 골다공증 예방 등의 효능이 알려진 $\beta$-cryptoxanthin 성분은 하레조생의 수확시기인 11 월과 12 월의 과육부분에서 함량이 가장 높았고, 완숙될수 록 함량이 증가하는 것을 확인할 수 있었다. 본 연구 결과에 따라 하례조생은 당 함량이 높고 산 함량이 낮아 맛이 우수 
하여 생과로서의 품질도 우수하고, 폴리페놀류 화합물, flavonoid, carotenoid 등 다양한 유용성분을 함유하고 있어 강한 항산화 활성을 보이므로 국내 육성 품종인 하례조생은 기능성 천연 소재로 식품과 화장품의 원료의 활용 가능성이 높을 것으로 여겨진다.

\section{감사의 글}

본 성과물은 농촌진흥청 연구사업(세부과제: PJ013831012019) 의 지원에 의해 이루어진 것입니다.

\section{References}

1. Jeon S, Kwon H, Han S, Lee J, Cho Y (2014) Antioxidant effect of Korean royal jelly in oxidative stress induced HepG2 cell. J Apic, 29, 305-311

2. Kim J, Kim J, Bae JS (2016) ROS homeostasis and metabolism: a critical liaison for cancer therapy. Exp Mol Med, 48, e269

3. Wojsiat J, Zoltowska KM, Laskowska-Kaszub K, Wojda U (2018) Oxidant/ antioxidant imbalance in Alzheimer's disease: therapeutic and diagnostic prospects. Oxid Med Cell Longevity, 1-16

4. Azadmanesh J, Borgstahl GEO (2018) A review of the catalytic mechanism of human manganese superoxide dismutase. Antioxidants, 7, 1-16

5. Temple MD, Perrone GG, Dawes IW (2005) Complex cellular responses to reactive oxygen species. Trends Cell Biol, 15, 319-326.

6. Cha BC, Lee EH, Noh MA (2005) Antioxidant activity of Spatholobus suberectus Dunn. Korean J Pharmacogn, 36, 50-55.

7. Lee SG, Ra JH, Song JY, Gwak CH, Kwon HJ, Yim SV, Hong SP, Kim JJ, Lee KH, Cho JJ, Park YS, Park CS, Ahn HJ (2011) Extracts from Citrus unshiu promote immune-mediated inhibition of tumor growth in a murine renal cell carcinoma model. J Ethnopharmacol, 133, 973-979

8. Li S, Pan MH, Lo CY, Tan D, Wang Y, Shahidi F, Ho CT (2009) Chemistry and health effects of polymethoxyflavones and hydroxylated polymethoxyflavones. J Funct Foods, 1, 2-12

9. Nicolosi E (2007) Citrus Genetics, Breeding and Biotechnology. In: Origin and taxonomy, Khan I (Editor), CAB International, Oxfordshire, UK, p 19-43
10. Fang YZ, Yang S, Wu G (2002) Free radicals, antioxidants and nutrition. Nutrition, 18, 872-879

11. Valko M, Leibfritz D, Moncol J, Cronin MTD, Mazur M, Telser J (2007) Free radicals and antioxidants in normal physiological functions and human disease. Int J Biochem Cell Biol, 39, 44-84

12. Park WS (2011) Effects of Red Ginseng-Ejung-tang and White Ginseng - Ejung -tang water extract on hydrogen peroxide production in RAW 264.7 cells. Korean J Orient Physiol Pathol, 25, 78-83

13. Singleton VL, Orthofer R, Lamuela-Raventos RM (1999) Analysis of total phenols and other oxidation substrates and antioxidants by means of Folin-Ciocalteu reagent. Methods Enzymol, 299, 152-178

14. Blois MS (1958) Antioxidant determination by use of a stable free radical. Nature, 181, 1199-1200

15. Re R, Pellegrini N, Proteggente A, Pannala A, Yang M, Rice-Evans C (1999) Antioxidant activity applying an improved ABTS radical cation decolorization assay. Free Radic Biol Med, 26, 1231-1237

16. Marcocci L, Maguire JJ, Droy-Lefaiz MT, Packer L (1994) The nitric oxide-scavenging properties of Ginkgo biloba extract EGB 761. Biochem Biophys Res Commun, 201, 748-755

17. Kunchandy E, Rao MNA (1990) Oxygen radical scavenging activity of curcumin. Int J Pharm, 58, 237-240

18. Benzie IFF, Strain JJ (1996) The ferric reducing ability of plasma (FRAP) as a measure of "antioxidant power": The FRAP assay. Anal Biochem, 239, 70-76

19. Kim EJ, Choi JY, Yu MR, Kim MY, Lee SH, Lee BH (2012) Total polyphenols, total flavonoid contents, and antioxidant activity of Korean natural and medicinal plants. Korean J Food Sci Technol, 44, 337-342.

20. Lee MY, Yoo MS, Whang YJ, Jin YJ, Hong MH, Pyo YH (2012) Vitamin C, total polyphenol, flavonoid contents and antioxidant capacity of several fruit peels. Korean J Food Sci Technol, 44, 540-544.

21. Rice-Evans C, Miller NJ, Paganga G (1997) Antioxidant properties of phenolic compounds. Trends Plant Sci, 2, 152-159.

22. Kim SS, Park KJ, An HJ, Choi YH (2016) Citrus platymamma inhibits the expression of pro-inflammatory cytokines, inducible nitric oxide synthase, and cyclooxygenase-2 in RAW264.7 macrophage. Korean J Food Preserv, 23, 1026-1032

23. Imai J, Ide $\mathrm{N}$, Nagae $\mathrm{S}$, Moriguchi $\mathrm{T}$, Matsuura $\mathrm{H}$, Itakura Y. (1994) Antioxidant and radical scavenging effects of 
aged garlic extract and its constituents. Plant Med. 60, 417-420

24. Shih MF, Cheng YD, Shen CR, Cherng JY (2010) A molecular pharmacology study into the anti-inflammatory actions of Euphorbia hirta L. on the LPS-induced RAW 264.7 cells through selective iNOS protein inhibition. J Nat Med, 64, 330-335

25. Tsatsanis C, Androulidaki A, Venihaki M, Margioris AN (2006) Signalling networks regulating cyclooxygenase- 2 . Int J Biochem Cell Biol, 38, 1654-1661

26. Park JW, Lee YJ, Yoon S (2007) Total flavonoids and phenolics in fermented soy products and their effects on antioxidant activities determined by different assays. Korean J Foods culture, 22, 353-358
27. Hertog MGL, Hollman PCH, Putte B van de (1993) Content of potentially anticarcinogenic flavonoids of tea infusions, wines and fruit juice. J Agric Food Chem, 41, 1242-1246

28. Sugiura M, Nakamura M, Ogawa K, Ikoma Y, Ando F, Yano M (2008) Bone mineral density in post-menopausal female subjects is assiciated with serum antioxidant carotenoids. Osteoporosis Int, 19, 211-219

29. Ni Y, Nagashimada M, Zhan L, Nagata N, Kobori M, Sugiura M, Ogawa K, Kneko S, Ota T (2015) Masuko kobori, prevention and reversal of lipotoxicity-induced hepatic insulin resistance and steatohepatitis in mice by an antioxidant carotenoid, $\beta$-cryptoxanthin. Endocrinology, 156, 987-999 